\section{Desplegando las capacidades políticas del diseño}

UNFOLDING THE POLITICAL CAPACITIES OF DESIGN

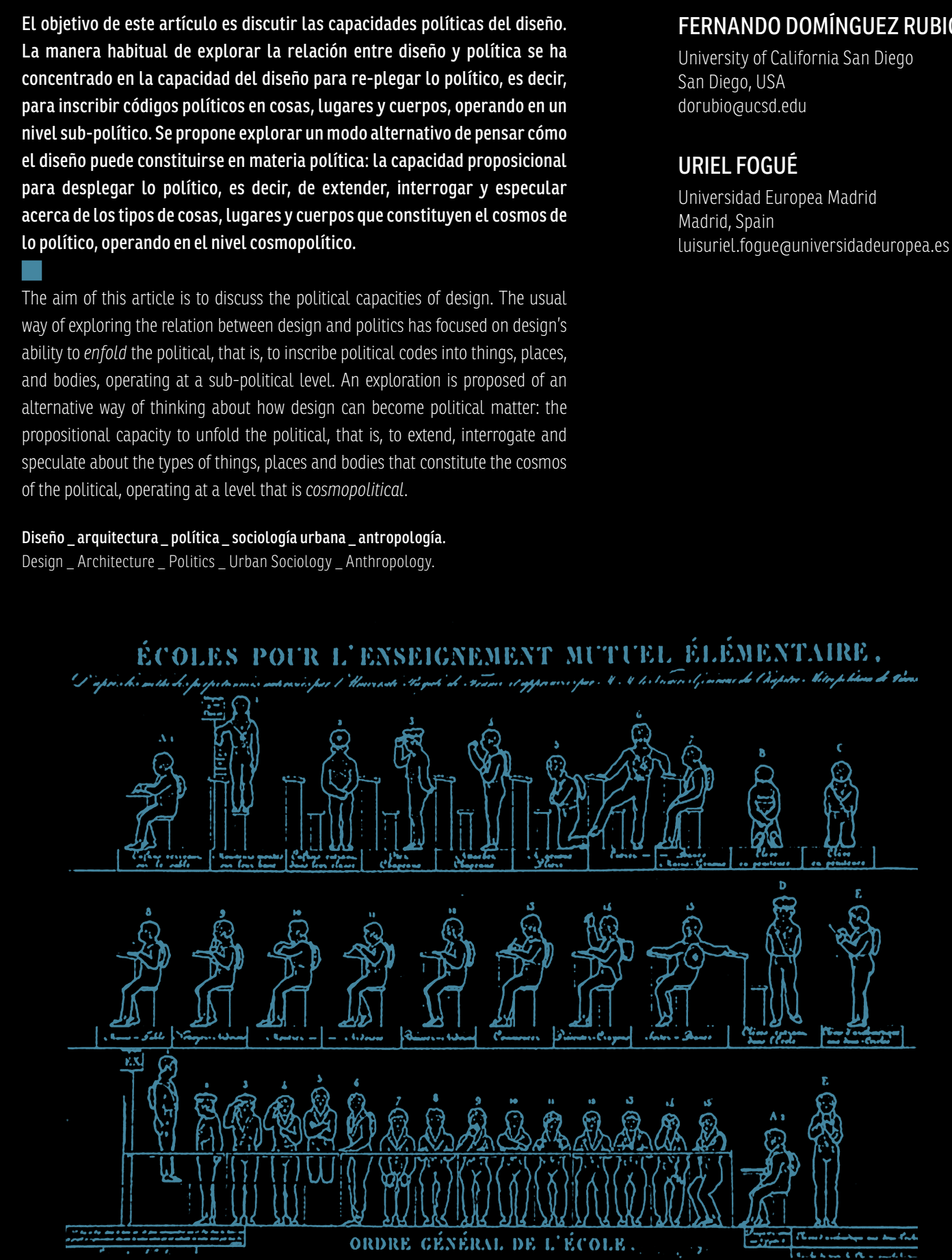

¿QUÉ SON LAS CAPACIDADES

POLITICAS DEL DISEÑO?

El objetivo de este ensayo es explorar cómo el diseño puede constituirse en materia política. $O$ dicho más

específicamente, el ensayo pretende explorar la capacidad del diseño para reorganizar aquello que cuenta como político en nuestras vidas diarias. Hasta ahora, la maner usual de explorar la relacion entre diseño y politica ha estado centrada en lo que podriamos llamar la capacidad de parn ocuerpos. Como resultado de este enforue l mayorí de las discusiones acerca de la capacidad política del diseño han oscilado entre dos posiciones aparentemente irreconciliables: los apologistas - aquellos que celebran esta capacidad de repliegue del diseño para prescribir programas - y los críticos -que ven en este re-pliegue un forma silenciosa de reproducción del poder En este texto queremos explorar un modo alternativo de pensar las capacidades politicas del diseño. Para hacerlo, lo en lo que lla maremos la capaciad del diseño para "desplegar" manera de explorar la valencia política del diseño, una que no gira en torno a su habilidad de prescribir políticas cuerpos, espacios o materiales, sino en torno a su capacida para extender el rango de cuerpos, espacios y materiales que constituyen el cosmos de lo político. Este cambio, sostenemos, abre no solo una nueva manera de pensar acer del diseño, sino también una manera distinta de practicar

\section{RE-PLEGANDO LO POLITICO}

El diseño siempre ha sido un oscuro objeto del deseo político. Parte de su atractivo reside en su habilidad para transformar lo explícito en implícito, lo visible en invisible, lo articulado en inarticulado, o lo externo en lo encarnado.

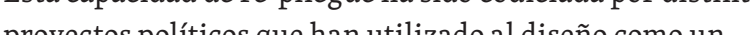
"mecto" que posibilitian un estratogia al diseño como un no contra las cosas, los lugares o los cuerpos, sino una que circule silenciosamente a través de ellos. El diseño, concebido de esta manera, emerge como una forma de hacer política a través de cosas, una forma que, además, ofrece la promesa de que el ejercicio del poder opere en un registro "subpolítico" a través del control de aquellos elementos físicos $y$ tecnologicos que silenciosamente conforman nuestras acciones y pensanientos, pero que tipicannente permanecen (Domín a nubio \& Fogú́, 2013: Ma Un de he nejors disc Una de las njores disctisions sobre las capacidades de encuentra en Foucult (g75) y su famosa disurín sobelo pupitres escolares en la Francia del siglo XVII Al establece y estandarizar los parámetros físicos de la postura "correcta" el diseño de estos pupitres requiere de una alineación
WHAT ARE THE POLITICAL

CAPACITIES OF DESIGN?

The aim of this essay is to explore how design can become political matter. Or stated more specifically, the essay seeks to explore the capacity of design to reorganize what counts as potitical in our everyday tives.

Until now, the usual way to explore the relation between design and polins has been centred around what we could to inscribe poitical programs the polincal. That is, tis abithy As a result of this perspective, most of the discussion arodes design's political abilities has oscillated between two extreme and seemingly irreconcilable positions: the apologists - those who celebrate this unfolding capacity of design in prescribing programs- and the critics - those who see in this unfolding a silent form of power reproduction.

In this text we would like to explore an alternative way of thinking about design's political capacities. To do so, we will focus on a different set of capacities, in we'd like to call design's ability to 'unfold the political, a perspective that, as we shall

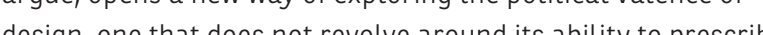
design, one hat does not revolve around its ability to prescribe to brooden the range of bodies spaces and materials that constitute the cosmos of the political. This shift, we argue, opens not only a new way of thinking about design, but also a different way of practicing design as a form of cosmopolitics.

ENFOLDING THE POLITICAL

Design has always been an obscure object of political desire Part of its attractiveness resides in its ability to transform the expliciti into the implicit, the visible into the invisible,
the articulate into the inarticulate or the external into the embodied. This enfolding capacity has been coveted by various political projects, which have employed design as a 'means' that allows a strategy of power to be exerted not against things, sites or bodies, but that can sitently circulate through them. Design, ths concenve, emiches as a for on dong poltics rendering of power works at a 'sub-political' the physical and technological elements that silently shape our actions and thoughts, but which typically remain outside the sphere of formal politics and institutions (Domínquez Rubio \& Fogué, 2013; Marres \& Lezaun, 2011).

One of the best discussions on the enfolding capacities of design used as a form of material politics is found in Michel Foucault's (1975) famous discussion of school chairs in seventeenth-century France. By setting and standardizing the of these chairs requires of a specific alignment between 
específica entre sujetos y objetos en un espacio conductual predefinido que silenciosamente inscribe al cuerpo dentro
de la esfera del poder disciplinar. En este sentido, sostiene Foucault, estas sillas conforman una de las microtecnologías críticas que permiten a una nueva logica de poder encarnar e inscribirse en el cuerpo (Figura 1). Las sillas no aparecen como instrumentos evidentes de poder, sino que operan en un registro sub-poltco creando silenciosamente la de poder disciplinario se repliega, de manera gradual, sobre el cuerpo. Tal y como señala Foucault, es gracias a estos mecanismos de re-pliegue que emerge una nueva lógicica de poder en la que este no requiere más de su representación pública para ser efectivo, ya que puede operar configurando una nueva microfísica del poder que tiene al cuerpo como campo de batalla invisible. De esta forma, concluye Foucau estos mecanismos envolventes hacen posible crear una diferentes sujetos sin que estos puedon dominación a la que están sujetos.

Otrogran ejemplo del usodebs capacides de re-pliegue del diseño puede encontrarse en la teoríá de la "delegación" de Bruno Latour. A diferencia de Foucault, Latour ofrece un discurso ampliamente laudatorio de estas capacidades. Tómese por ejemplo su famosa discusión acerca de los badenes reductores de velocidad. Según Latour (1999), los reductores de velocidad surgen como resultado de la imposibiliadad de confiar en la voluntad individual de los "onciences, o en la "w" a de lo que Dur heim denomino por ejemplo, se aproximan a una escuela Los reductores de velocidad, argumenta Latour, resuelven este problema permitiendo la traslación de una demanda moral colectiva del tipo «reduzca su velocidad para evitar poner en riesgo a los estudiantes», en una demanda autointeresada del tipo «debo aminorar la velocidad para proteger la suspensión de mi coche» (1999, pág. 186). De este modo, al igual que operan como mecanismos sub-politicos que hacen posible re-plegar silenciosamente una versión específica de "civilidad" y de "bien público" en el asfalto. Ahora bie al contrario de lo que ocurre en el caso de Foucault, este proceso de repliegue es visto por Latour de forma positiva. Para Latour, este repliegue hace posible que el diseño opere como un mecanismo positivo en la creación y reproducción del orden (civil), gracias a su capacidad para crear "cajas negras", como estos badenes, en las que pueden delegarse

Nuestro objetivo en este artículo no es discutir acerca de los pros cor a de apogistas al modo de Latour o de crticos a respecto de si ambos bandos no habrán tal vez sobrestimado de igual manera la eficacia de las capacidades de re-pliegue del diseño. De hecho, y a pesar de sus diferencias, al parecer ambos tienden a considerar la performatividad del diseño como un hecho al asumir lo que el diseño nos hace hacer.
En otras palabras, ambos tienden a crear una "ilusión performativa" a enfocarse en las intenciones y programas que resultado inevitable de un diseño original.
Con

Con esto no queremos decir que las capacidades de repliegue del diseño sean una mera ilusión. Basta con mirar a cómo el diseño es capaz de crear formas de poder blandas y tácitas que influyen en muchas de nuestras conductas $y$ decisiones colidinas (hhaler \& Sunstein, 2008; Schüll, 2012). Ahora blen, es tan importante tener en cuenta estas nos recuerda Harvey Molotch (2003) los objetos de diseño cambian constantemente a medida que las personas se reapropian de ellos y los diseñadores tratan de dar sentido y adaptar estas re-apropiaciones. Después de todo, el propio Foucault probablemente se sentó en alguno de estos pupitres y estuvo sujeto a múltiples mecanismos disciplinares cuidadosamente diseñados $y$, a juzgar por su magníica ob estos no lograron gran cosa en términos de disciplinarlo de manera exitosa. De igual forma, aunque es cierto que en hacer cumplir los mandatos de civismo y moralidad pública, también es innegable que los conductores siempre terminan por encontrar modos de evitarlos y yesquivarlos. "ilusión performativa" que los que podemos encontrar en proyectos que buscaron utilizarar la arquitectura para replega de prabado Lerbis para noderizar y lugar para tender la ropa -0 aquellos edificios ideados por los arquitectos constructivistas para diseñar un nuevo tipo de individuo para la sociedad comunista, denominados "condensadores sociales", y que hoy yacen abandonados como ruinas de un mundo que nunca fue (Figuras 2a y 2b). como un comentario irónico respecto de las capacida de re-pliegue del diseño arquitectónico. Ahora bien, nuestra intención no es usar esta ironía para desacreditar las capacidades politicas del diseño. Muy por el contrario:

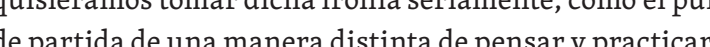
el diseño. Dicho de otro modo: la irónica suerte de estos proyectos nos fuerza a reconocer los límites de las capacidades políticas del diseño y a examinar la brecha irreductible que hay entre los programas que se pretenden inscribir a través del diseño y la manera en que estos son percibidos. activados, transformados o simplemente ignorados. Lo que argumentamos es que aceptar los límites del diseño, en vez intentar superarlos con nuevos y "mejores" diseños, abre una constituirse como materia política.

What we argue is that to accept the limits of design, rather than trying to overcome them with new and 'better' designs, opens up a different way of thinking about how design can become political matter.

This, needless to say, does not mean that the enfolding capacities of design are a mere illusion. We just need to look of creating soft and tacit forms of power that influence many of our danily behaviours and decisions (Thaler \& Sunstein, 2008;

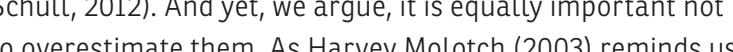
adapt to these re-appropriations. After all, Foucaut himseff probably sat in one of those chairs and was subjected to a myriad of carefully designed disciplinary mechanisms and, judging from his magnificent oeurre, they did not achieve much in terms of successfully disciplining him. Likewise, though it's true that speed bumps are relatively successful in enforcing that drivers a them. There are perhaps no better examples to illustrate this architecture to enfold different visions of a new society, like Le Corbusier's project to modernize Chandigarh - eventually those buildings conceived by constructivist architects to design a new type of individual for the communist society, the ruins of a world that never was (Figure 2).

The tragic fate of these projects can be seen as an ironical commentary on the enfotcing capactities of architectural design. political capacities of design Quite the opposite we wish to take this irony seriously as the starting point of a different way of thinking and practicing design. In other words, the ironical fate of these projects forces us to acknowledge the limits of the political capacities of design and to examine the irreducible gap that separates the programs enfolded through design and how What we areved, activated, transformed or simply ignored. Wying to overs hat to accept the timits of design, rather tha a a different way of think new and better designs, opens political matter.

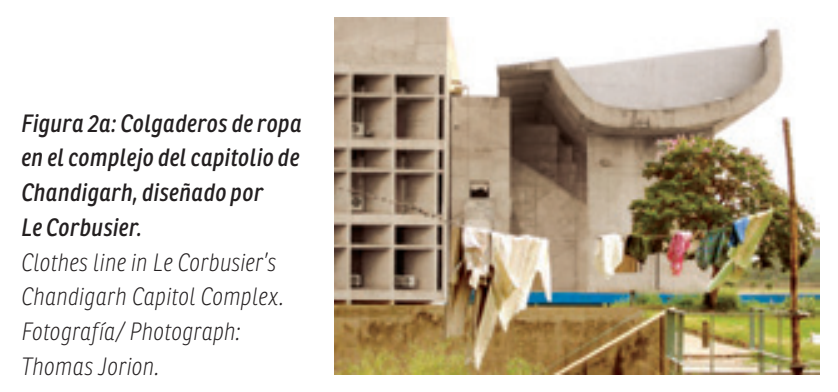
nuestro alrededor para encontrar ejemplos que demuestran Aunque quizá no existan mejores ejemplos para ilustrar esta el área del urbanismo y la arquitectura. Baste solo pensar en la suerte que han corrido todos aquellos grandilocuentes

La trágica suerte de estos proyectos puede ser vista design objects are continually changing as people creatively "performative illusion" than the ones we can find in the areas the fate of those grandiloguent projects that sought to use turned into a flea-market and a place to hang clothes - or

diseños, abre una nueva manera de pensar

en los modos en que el diseño puede constituirse como materia política. 

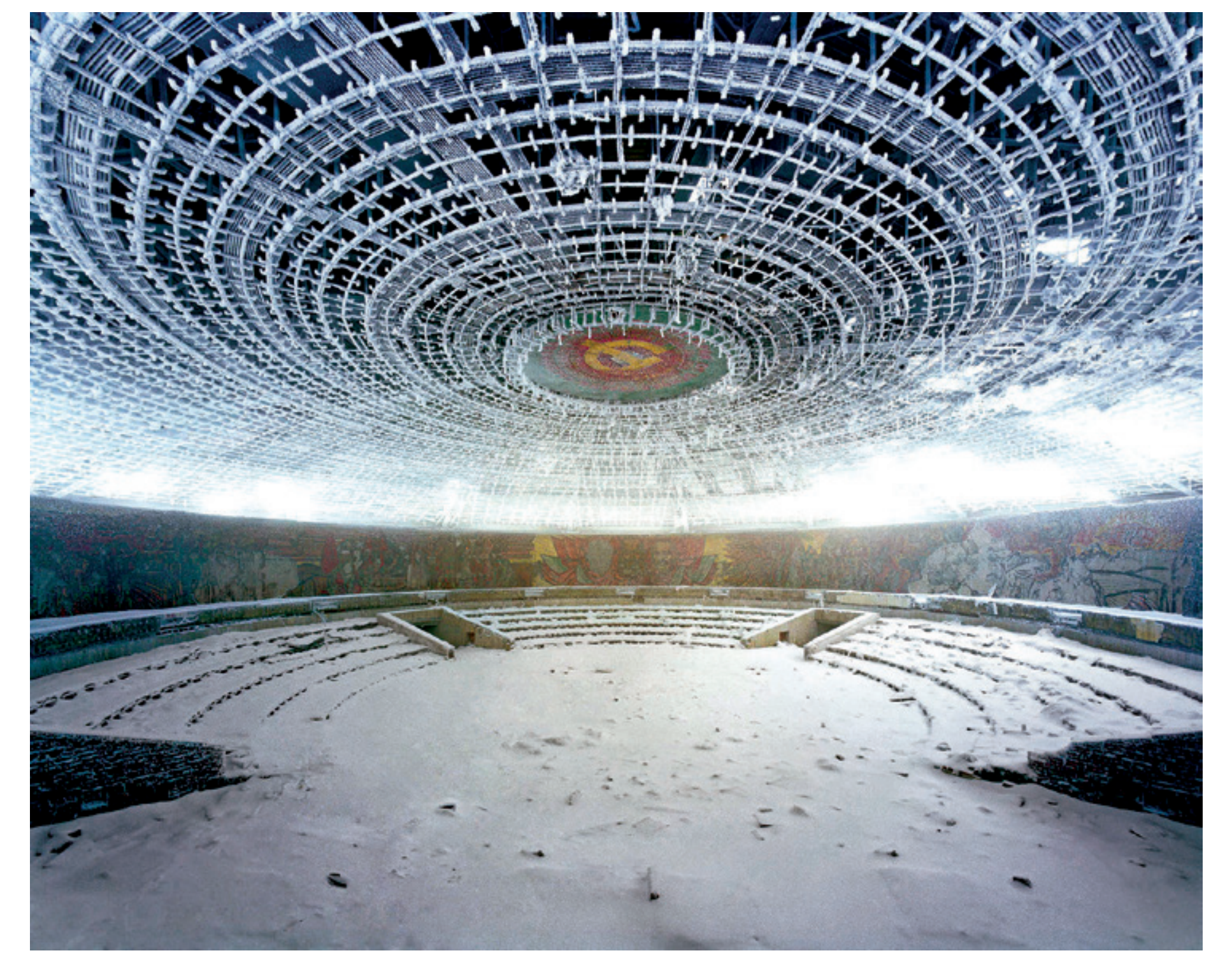

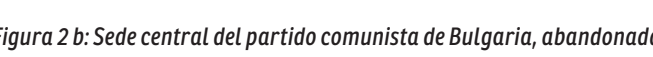

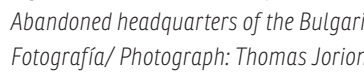

DESPLEGANDO LO COSMOPOLÍTICO Antes de que podamos definir lo que entendemos or desplegar, es necesario establecer qué es lo que no desplegar sea lo contrario de re-plegar. O, dicho de otra manera: por desplegar no nos referimos a un proceso de hacer visible o "descajanegrizar" lo que anteriormente se encontraba re-plegado. Más aún, desplegar tampoco es una crítica del re-plegar. Por desplegar, entonces, no nos referimos a un proceso "revelador" " critico", sino al proceso de hacer posible y visible una proposición. Una manera $\mathrm{de}$ afirmando que mientras re-plegar se refiedades podría ser del diseño de "inscribir" versiones específicas de lo político en diferentes cuerpos, entidades y lugares, el proceso de en diferentes cuerpos, entidades y ugares, el proceso de
desplegar se refiere a la capacidad del diseño de "proponer como politicos nuevos tipos de cuerpos, entidades y lugares. tolding. By unfolding, then, we are not referring to a a proposition possible and visible. One way of explaining the difference between both capacities could be to say that while versions of the poltistin's capacity to "inscribe" specific the process of unfolding refers to the capacity of design to 'propose' new kinds of bodies, entities and sites as political.
Es en este sentido, argumentamos, que desplegar puede ser definido como una actividad "cosmopolítica". Tal como señala I Isabel Stengers (2005), la cosmopolítica no trata
de unificar el mundo, sino de multiplicarlo. El diseño, afirmamos, puede jugar un rol crítico en este proceso desplegando y explorando posibilidades hasta ahora irrealizadas de construir el cosmos de lo político. Tal como plantearemos a continuación, esto se puede lograr al menos

AMPLIANDO EL COSMOS DE LO POLITICO

Las capacidades de despliegue del diseño pueden ser utilizadas para ampliar aquello que puede constituirse com materia política. Un buen ejemplo puede ser encontrado en las tecnologias de monitorización domestica, como los medidores inteligentes de energía. El objetivo de estas tecnologlas es hacer que la "energia se torne visible y controlable a través de mecanismos de visualización, por consumo do a sus costos asociados (Figura 3).

Una manera de discutir la valencia política de estos artefactos sería poner el foco en sus capacidades de re-pliegue, ejemplificadas, entre otras cosas, en la capacidad de estos aparatos para interactuar con niveles nuevo sentido de conciencia acerca de la energía. Acá, sin embargo, quisiéramos enfocarnos en un conjunto distinto de capacidades: la capacidad de estos artefactos para desplegar espacios y acciones domésticas como posibles lugares para la politica. Esto lo pueden lograr de diversas maneras. Por ejemplo, dichos artefactos abren las posibilidades de desdibujar la distinción entre prácticas cotidia y u nos on aparentemente munda a ine integradas en otras escalas de acción más allá del hogar. La capacidad de estas tecnologías para hacer que una fuerza abstracta como la energía se torne visible, evidente y cuantificable, abre la posibilidad de entreverar actividades "privadas" en proyectos políticos de mayor envergadura, tales como sociedades sustentables o economias bajas en carbono. De este modo, estos artefactos ofrecen la posibilidad de comprender el hogar no tanto como un espacio autocontenido y privado, sino como u espacio en el que se pueden articular diversas formas de acción, participación y asociación politica (Marres, sobre contaminación (Calvillo, 2014) Lo que este ejemplo muestra, por lo tanto es cómo 20rtefactos aparentemente mundanos permiten desplegar la posibilidad de redescribir acciones cotidianas y espacios domésticos cono marcos políticos, y cómo, al hacerlo, amplían el cosmos de lo político al extender el repertorio de lugares posibles para la acción y las formas de participación política.
It is in this sense, we argue, that unfolding can be defined as a 'cosmopolitical' activity In Isabelle Stengers's use, cosmopolitics is not about unifying the world, but about multiplying it. Design, we argue, can play a critical role in this process by unfolding and exploring hitherto unrealized possibities to build the cosmos of the potitical. As we will

ENLARGING THE COSMOS OF THE POLITICAL

The unfolding capacities of design can be employed to enlarge what counts as political. A good example can be found in current domestic monitoring technologies, like smart energy meters. The aim of these technologies is to render 'energy' for exama controllable through visualization mechanisms, of individual domestic appliances, or software programs that make indicate real-time energy consumption and its associated costs (Figure 3).

One way of discussing the political valence of these devices would be to focus on their enfolding capacities, tha is, on how these devices are capable of interacting with the sense of awaness about energy. Here, how to focus on a different set of capacities: the capacity of these devices to unfold domestic spaces and actions as possible sites of politics. They can do so in various ways. For example, these devices open up the possibility of blurring the distinction between public and private spaces or between political actions and everyday practices by showing how seemingly mundane and ineffectual quotidian actions can be integrated into other scales of action beyond the home. They can achieve this is by rendering an abstract force like energy into something visible, evident and quantifable, opening up the possibility of connecting these 'private' activities with larger political projects way, these artifacts offer the possibility to understand the home not so much as a self-contained and private space, but as a space where different forms of political action, participation and association can be articulated (Marres, 2012) or from which to challenge the official discourses about pollution (Calvillo, 2014). What this example shows, therefore, is how seemingly mundane design devices unfold the possibility of re-describing everyday actions and domestic spaces as poltical frameworks and how, in so doing, they enlarge the cosmos of the political by

extending the repertoire of possible sites for political action and

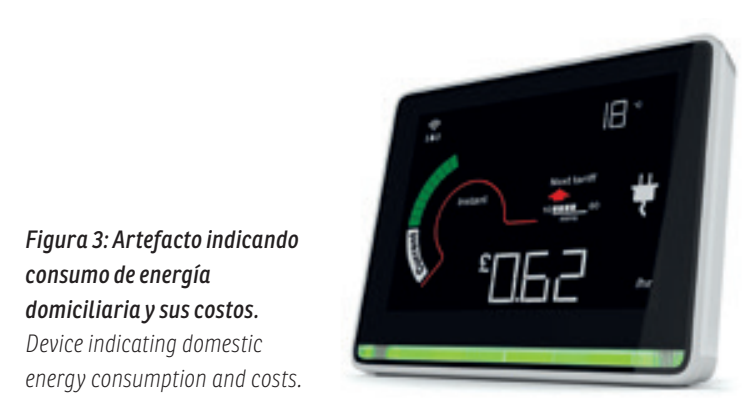



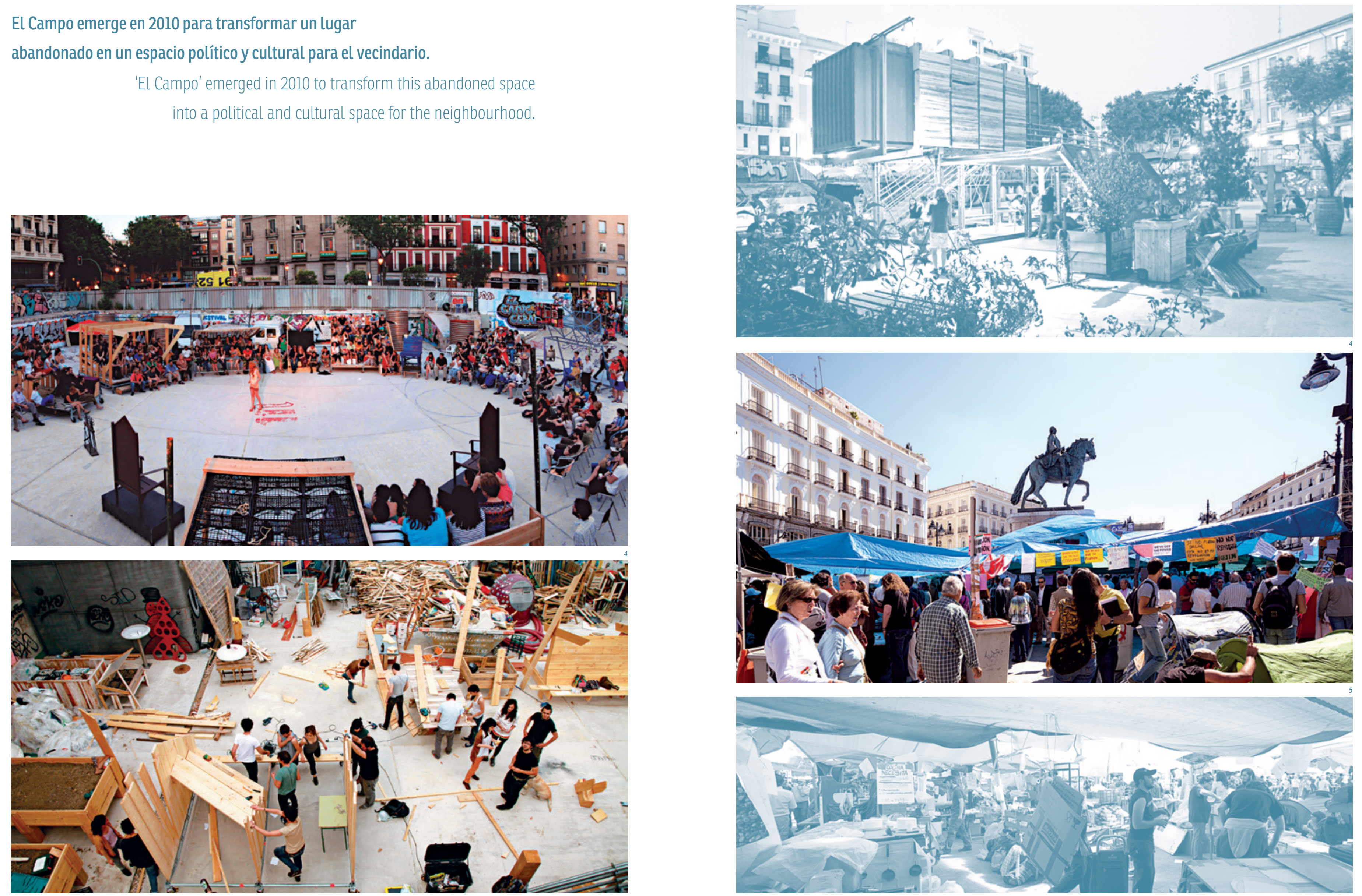
ESPECULANDO ACERCA DEL COSMOS DE LO POLITICO La segunda manera en la que el diseño puede desplegar es cosmos de lo politico es a través de la especulación. Por de desplegar lo "insosspechado" como lugar para la acción e imaginación política.

Un ejemplo de las capacidades politicas de estas tácticas especulativas puede ser hallado en El Campo de la Cebada en Madrid. El Campo emerge en 2010 para transformar un lugar abandonado en un espacio politico y cultural para el decinaíín espećf́ca o programa político sob-plegar una se eligió crear un espacio infradeterminado que pudiese ser desplegado y activado de distintas maneras. Para ello, la plaza fue equipada con un conjunto de elementos de mobiliario urbano de código abierto que permitiese múltiples posibilidades y configuraciones (Figura 4).

La valencia politica de EI Campo reside en haber logrado crear un espacio perennemente indefinido que puede ser reimaginado de manera infinita; permaneciendo así como en un estado en "beta" de manera permanente (Corsin Jiménez, 2014) que puede ser explorado a través de cada una poderosa máquina en la cual ps posibe experimenta otros modos de estar en la ciudad, de construir comunidades urbanas, de explorar maneras de crear apegos, tanto materiales como emocionales, así como de experimentar con otras formas de participación política.

Otro poderoso ejemplo puede encontrarse en los movimientos "occupy" dispersos a traves del mundo desde 2011. A pesar de sus distintas historias y trayectorias, todos estos movimientos han intentado apropiarse de plazas publicas que habian sido (o estaban en vias de ser) re-plegada ocupaciones no solo transformaron estas plazas en "espacios políticos", sino también y lo que es más importante, en sitios para la "especulación política", esto es, en sitios en los cuales se hizo posible pensar, explorar y probar formas insospechadas de hacer o pensar la política. Tómese, por ejemplo, el caso de la Acampada Sol' en Madrid en mayo de 2012 (Figura 5). que llegóa a ganar el Concurso Europeo de Diseño Público el mismo ano. La Acampada fue un objeto de diseño abierto posibilidades eran discutidas y testeadas on destintos comités y grupos de trabajo en un á́ora política al aire libre. Es importante señalar que el objetivo de esta arquitectura no fue la materialización de un proyecto previo, sino crear estructuras que pudiesen «activar pensamiento» (Stengers, 2005, pág. 1.001). En otras palabras, lo que se trato de hacer fue transformar la plaza en un laboratorio a escala real, en un lugar donde fuese posible imaginar y especular sobre las políticos y modos de participación y organización política. En este sentido las acampadas desplegaron y activaron la posibilidad de una cosmología política diferente basada en un nuevo vocabulario político y en un nuevo repertorio de prácticas y formas de asociación política insospechadas hasta el momento (Figura 6).
SPECULATING ON THE COSMOS OF THE POLITICAL

The second way in which design can unfold the cosmos of the political is through speculation. By speculation we mean here the capacity of design to unfold

poltical action and imagination. One example of the political capacities of these speculative
tactics can be found in El Campo de la Cebada in Madrid. 'El Campo' emerged in 2010 to transform this abandoned space into a political and cultural space for the neighbourhood. Rather than trying to inscribe a specific definition or program into the square, promoters chose to create an under-defined space that could be unfolded in different ways. To make this mobile urban furniture that enabled multiple possibilities an configurations (Figure 4).

The political valence of El Campo resides in having created a perennially undefined space that can endlessly be re-image it remains 'in beta' as a space of possibilities (Corsín Jiménez, 2014) that can be explored through each new unfolding. In ths sense, El Campo emerges as a powerful machine in which it is possible to experiment with other ways of being in the city, other forms of building urban communities, other forms of creating material and emotional attachments, and also other forms of pollical participation.

Another powerful example can be found in the 'occupy' movements spread across the world since 2011. In spite of their attempted to anpropriate public squares that were (or were about to be) enfolded in hegemonic political and economic

projects. The occupations transformed these squares not only into 'political sites', but also, and much more importantly, into sites of 'political speculation', sites on which it became possible to think, explore and test other possible forms of poltitics. Take, for example, the case of the 'Acampada Sol' in Madrid in May 2012 (Figure 5), which went on to wint the European Public Design Competition in the sameyear. The 'Acampada' was an and possibithes merged and were disursed and tested in the different committess and working groups in an open-air political agora. It is important to point out that the aim of this architecture was not to materialize a previous project, but to create structures that would "activate thinking" (Stengers, 2005, p. 1.001). In other words, what was attempted was to transform the square into a life-size laboratory, into a place where it was possible to speculate about the potentialities (and timits) of aifferent political vocabula

In this sense, the acampadas unfolded and activated the possibitity of a different political cosmology, one based on practices and forms of politicat association, until that moment unsuspected (Figure 6).

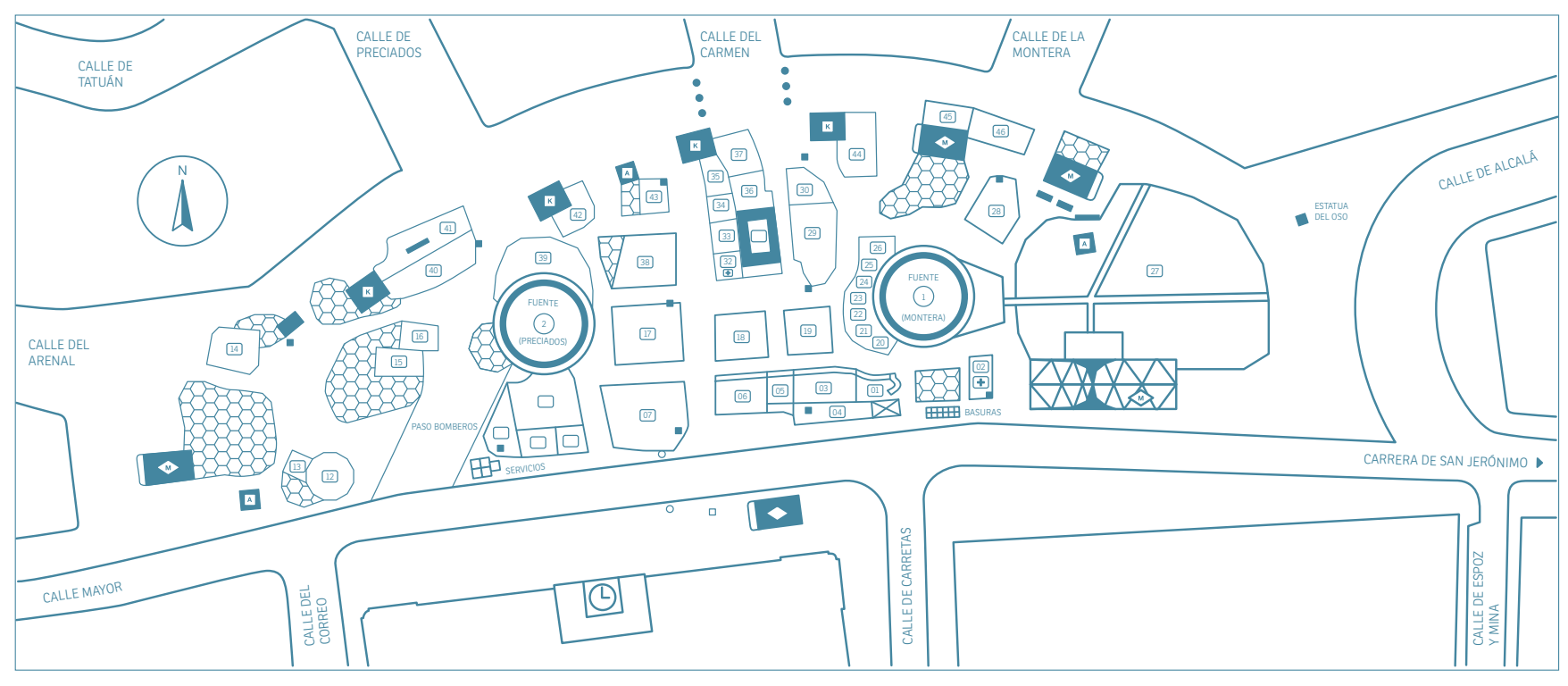

8 sogna acampada

Figura 5: Mapa dele " "acampadd Sol"

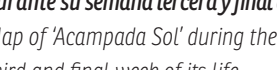

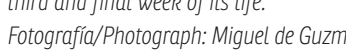

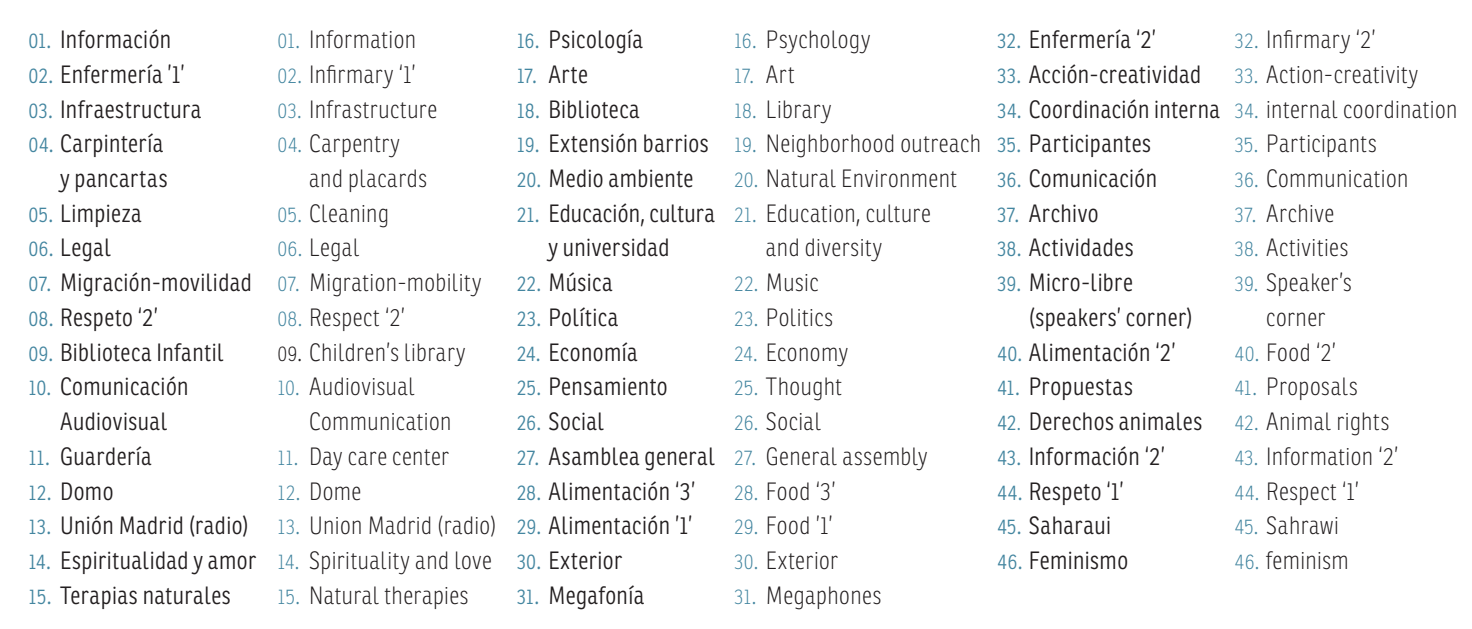

La Acampada fue un objeto de diseño abierto que creció orgánicamente a medida que nuevas ideas y posibilidades eran discutidas y testeadas en los distintos comités y grupos de trabajo, en un ágora política al aire libre.

The 'Acampada' was an open-ended design object that grew organically as new ideas and possibilities emerged and were discussed and tested in the different committees

and working groups, in an open-air political agora. 


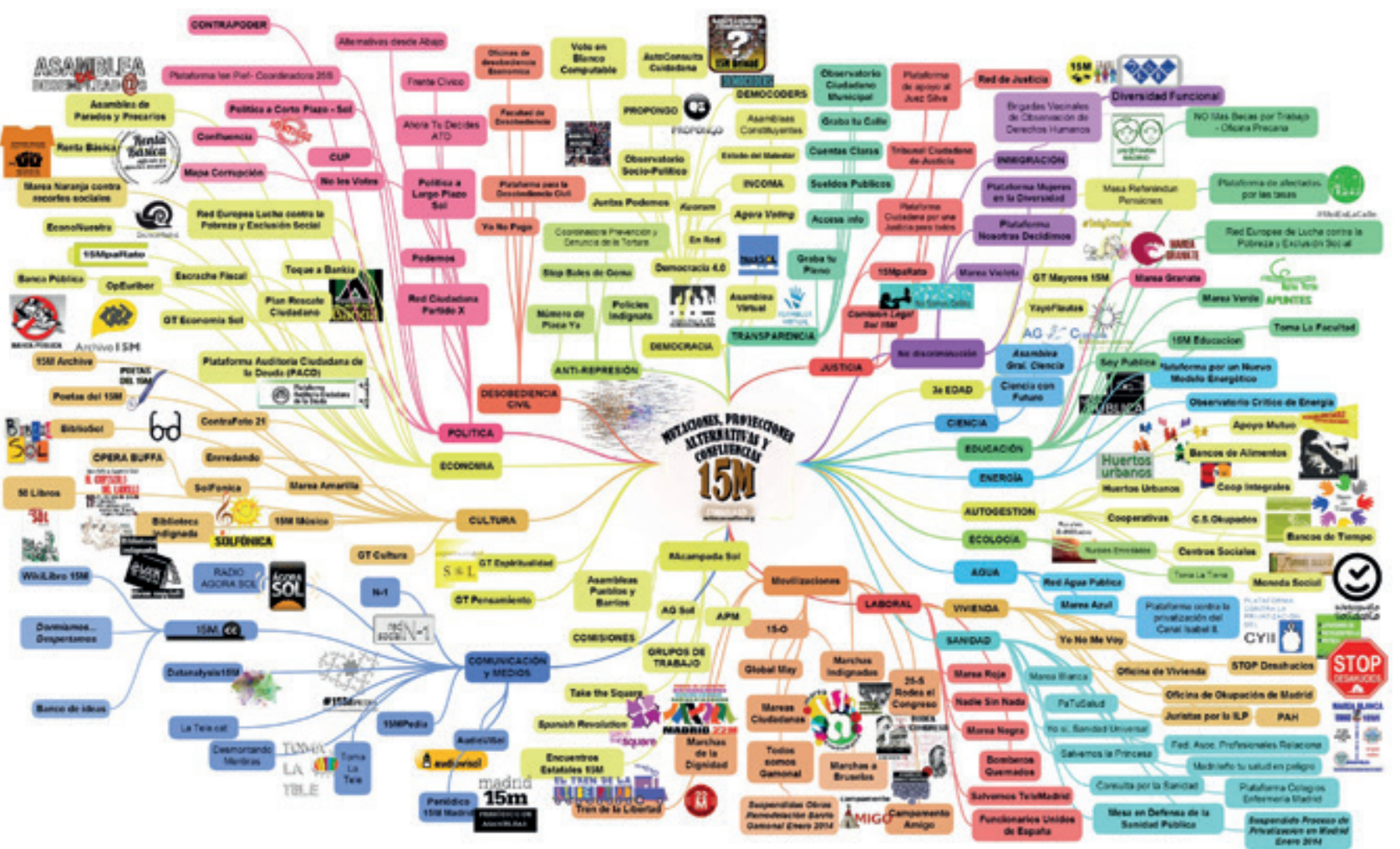

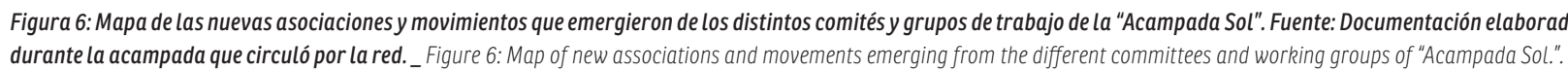

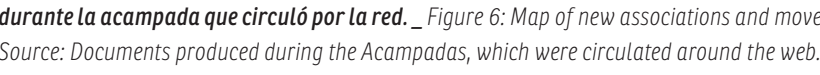

Con los ejemplos de esta seccín hemos querido explorar algunas de las maneras en las que el diseño y el diseño arquitectónico politica. Los ejemplos son intervenciones efimeras que no están diseñadas para perdurar. Aun asi, su fugacidad no 1 as ace menos poderosas oimportantes, dado que su poder no de en su topactad para hacer que determinadas visio para hace ths importante proporción de la actividad polítca institucion en España ha girado, precisamente, en torno a explorar la posibilidades que las plazas desplegaron. En este sentido, poder de estas intervenciones reside en su capacidad para lugar de acción e imaginación política.

CUESTIONANDO EL COSMOS DE LO POLITICO

cómo el diseño puede desplegar el cosmos de lo político a través de su cuestionamiento. Más especificamente, queremos explor las capacidades politicas del diseño cuando es usado no a para proveer respuestas, sinocono

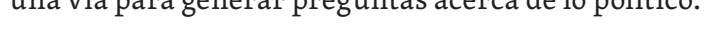
Nos centraremos en un ejemplo particular: la Jane Fonda Firi (wse, diseñada por la oficina española de arquitectura
With the examples in this section we have sought to explore some of the ways in which design, and architectural design in particular, can become political matter. These examples Yet their transience does not make them any less powerful or important, since their power does not reside in their ability to make certain visions of order physical or eternal, but in ther capacity to make hem thinkable. Al hough the acampodas institution aroul unfolded in the squares. In this sense, their power lies in their ability to activate and unfold the possibility of an otherwise for political action and imagination.

QUESTIONING THE COSMOS OF THE POLITICAL In this last section we want to explore how design can specifically, we want to explore the political capacities of design when it is used not as a tool to provide answers, but as a way to generate questions about the political. We will focus on a particular example: the Jane Fonda Kit House designe by the Spanish architectural studio Elii (www.elii.es). The prototipo para una "casa del futuro", inicialmente construida en Bruselas (2012) y luego reconstruida en la ciudad china de Cantón (2013). LaJF-Kit House se encuadra dentro de la de las clásicas casas del futuro, la I J-K-Kit House no intenta re-plegar o anticipar el futuro, ni pretende dar soluciones técnicas a los problemas del mañana. En cambio, opera como un modelo irónico que ayuda a radicalizar y testen la potencialidad y los limites de las promesas y utopias

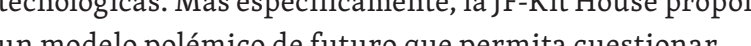
los discursos e imaginarios existentes en torno a la sustentabilidad y la arquitectura verde que habitualme se dan por sentado. Esto se consigue exacerbando el imaginario actual de sustentabilidad, al movilizar los cuerpos de sus habitantes y transformarlos en agentes activos en el proceso de producción de energía. Para ello, propone un escenario futuro radical de sustentabilidad en el cual los ciudadanos deben resolver todos sus requerimientos energéticos por medio de sus propias actividades fisicas. De este modo, la casa transforma

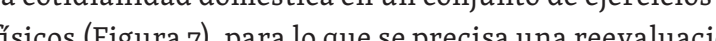
reformulación radical del espacio doméstico.

Mediante la raliealizcín ińnica de este nodo de Mediante la radcalle birica de este modelo de debate acerca de los cuerpos y Housé persigue es abrir el
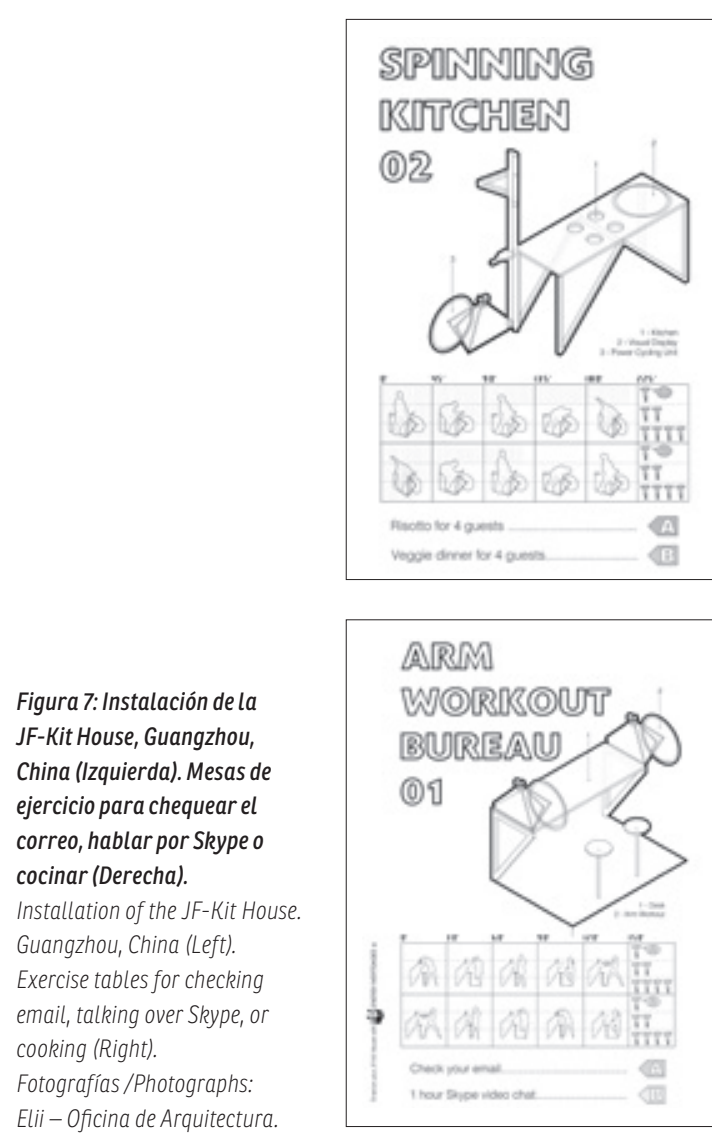

future', initially built in Brussels (2012) and later rebuilt in Guangzhou (2013). The JF-Kit House is inscribed within the (the houses of the future. Unlike

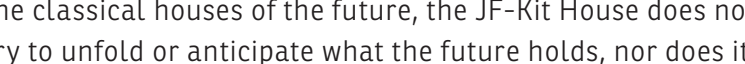
attempt to provide technical solutions for future problems, but instead serve as ironical models that help to radicalize and test the potentiality and limits of technological promises a polemic model of the future that can be used to question existing discourses and imagery about sustainability that are usually taken for granted. It does so by exacerbating the present imaginary on sustainability and green architecture, by mobilizing the bodies of its inhabitants and transforming them into active agents in the process of energy production. For this, it proposes a radical future scenario of sustainability in which citizens have to meet all of their domestic energy requirements wh h therr own physical actives. Thus, the physical exercises (Figure 7), for which a radical re evaluation and reformulation of domestic space is required.

Through the ironical radicalization of this model, what the JF-Kit House seeks is to open a debate about the kind of bodies and practices that are required to participate and achieve the imagined sustainable societies. Nevertheless, the
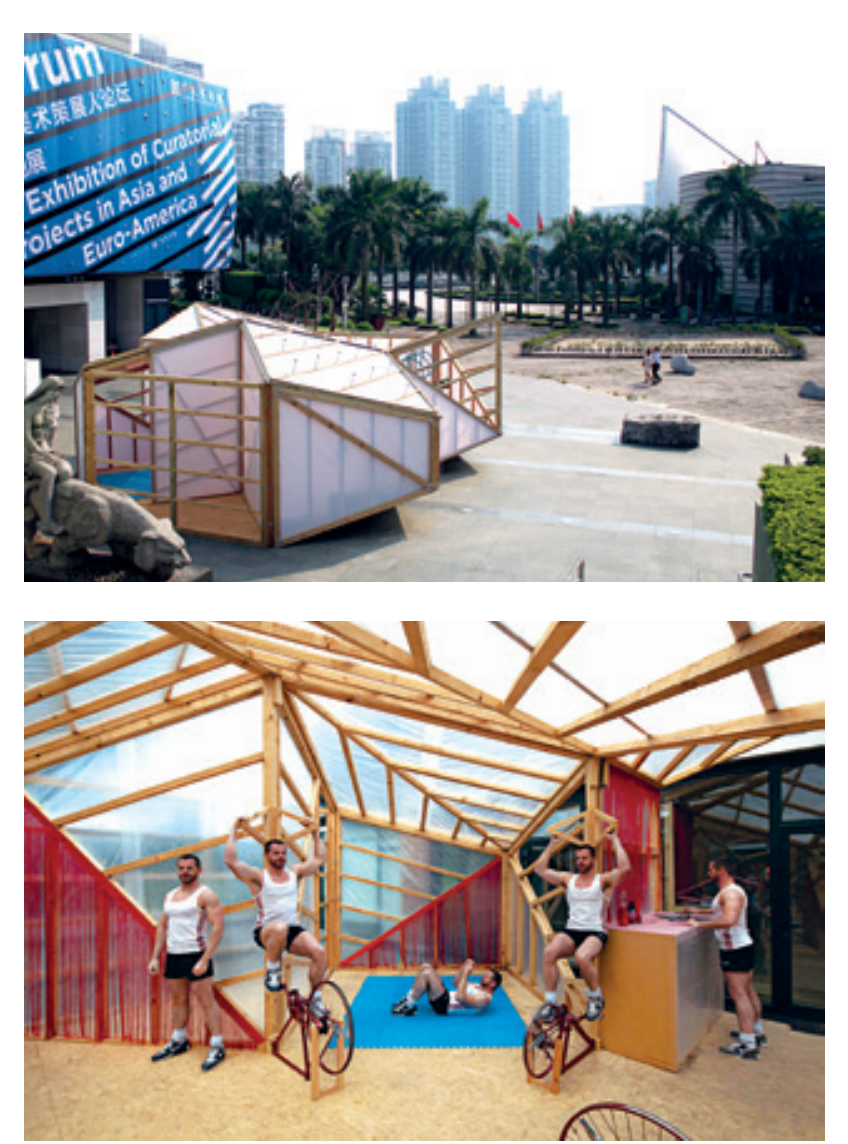
No obstante, la JF-Kit House plantea todos estos interrogantes, pero no trata de responderlos. En otras tecnocientífico habitual que proporciona respuestas dichas cuestiones. En su lugar, la JF-Kit House busca ser una "caja negra" en el sentido teatral del término, lo que equivale a decir que busca ser un espacio donde sea posib escenificar los problemas, hacerlos evidentes y públicos. El valor politico de la jF-Kt House, por lo tanto, no reside en su capacidad para ofrecer un modelo sustentable que ofrezca valor político reside en su capacidad para desplegro un escenario ficcional, un campo de juegs poĺ́mico en el cual la sustentabilidad emerge no como un problema técnico en busca de soluciones técnicas, sino como un problema político que requiere un nuevo sistema de cohabitación, un nuevo régimen cosmopolitico que demanda la producción no solo de nuevas tecnologias, sino tambièn de nuevos cuerpos, un nuevo conjunto de practicas culturales y un nuevo conjunto de conexiones y ensamblajes entre todos estos elementos. La J F-Kit House puede ser vista como un ejemplo dificios, sino que tambén seocupa de costruir pregutas y controversias.

\section{¿RE-PLEGAR 0 DESPLEGAR}

\section{ESA ES LA CUESTIÓN}

El objetivo de este breve ensayo ha sido discutir las capacidades políticas del diseño Al referimos a las capacidades políticas del diseño en lugar de a las habituales
"politicas del diseño" hemos intentado resaltar el hecho de que el diseño no posee una sola política, sino que es capaz de articular y generar distintas logicas y formas politicas. Hemos explorado aquí dos grupos de capacidades: por un lado, la capacidad de re-phiegue, la cual opera como un mecanismo prescriptivo; por otro, la capacidad de Hemos visto cómo mientras proceso de re pligene pernte al diseño producir respuestas a problemas políticos. el despliegue transforma al diseño en un mecanismo para generar preguntas y problemas políticos. Además, hemos comprobado cómo la capacidad de re-pliegue permite al diseño trabajar en el nivel de lo sub-politico al posibilitar la inscripción de determinados códigos politicos en cosas, lugares y cuerpos, mientras que la capacidad de despliegue le permite trabajar a nivel de lo cosmopolitico al posibilitar el lugares y cuerpos que constituy ace cos los te lo dítico. a preguta para nosotros, por consiguiente, lo to tanto cuál de estas capacidades es mejor o preferible, sino cuáles se ponen en uso y cómo pueden constituirse en una materia política. ¿Re-plegar o desplegar? Esa es la cuestión.
JF-Kit House raises all these questions but does not attempt to answer them. In other words, it does not aim to be a 'black House aims to be a 'black box' in the theatrical sense of the term, which is to say that it aims to be a space in which it is possible to stage problems, to render them evident and public. The political value of the JF-Kit House, therefore, does not reside in its capacity to offer a model of sustaina politicat alue lies in ts abilty to unfold a fictiona tscentro, a polemic playfield in which sustainability emerges not as a technical problem requiring a technical solution, but as political problem requiring a new system of cohabitation, new cosmopolitical regime which requires the production not only of new technologies but also of new bodies, a new set of cultural practices and a new set of connections and attachments between all these elements. The JF-Kit Hous can be seen as an example

\section{TO ENFOLD OR TO UNFOLD?}

\section{THAT IS THE OUESTION}

The aim of this short essay has been to discuss the poltical capacties of design. By takikng about the political design', we have aimed to hightight the fact that design does not have a single politics, but is capable of articulating and generating different political logics and forms. Here, we have explored two sets of capacities: on the one hand the capacity to enfold, which operates as a prescriptive mechanism; on the other hand, the capacity to unfold, which operates as a propositional mechanism. We've seen how the process of enfolding enables design to produce answers to polissal problems, whic untalng transforms design into Furthermore, weve confirmed how enfolding enables design to work at the level of the sub-political by making it possible to inscribe political codes into things, sites and bodies, while unfolding allows it to work at the level of the cosmopolitical by making it possible to extend, interrogate and speculate about the kinds of things, sites and bodies that constitute the cosmos of the political. The question for us, therefore, is not so much which of these capacities are better or preferable, politically. To enfold or to unfold? That is the question.

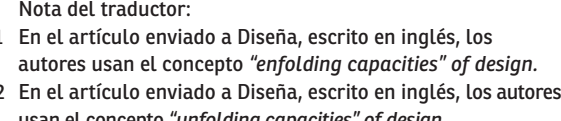

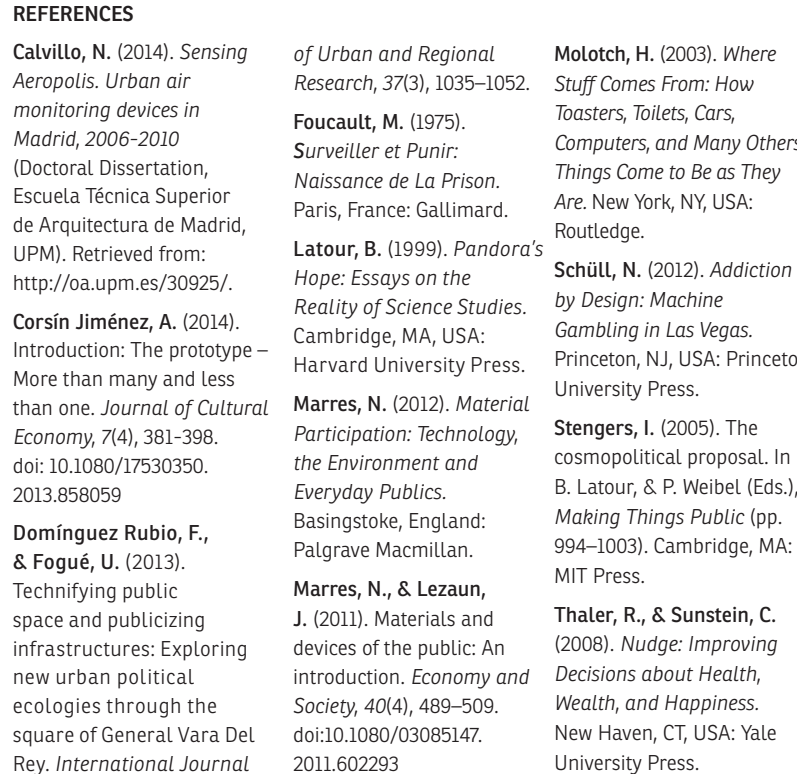

Hemos visto cómo mientras el proceso de re-pliegue permite al diseño

producir respuestas a problemas políticos, el despliegue transforma at

diseño en un mecanismo para generar preguntas y problemas políticos.

We've seen how the process of enfolding enables design to produce answers

to political problems, while unfolding transforms design into a mechanism to

generate political questions and problems.

FERNANDO DOMINGUEZ RUBIO

(a)

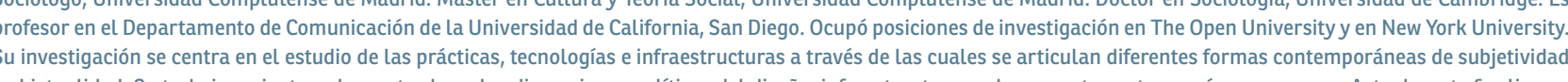
manuscrito basado en una etrnografifia realizada en el Museum of Modern Art (MoMA) de Nueva York

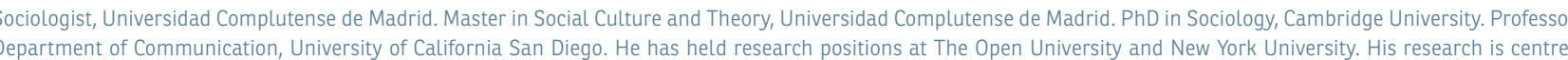
on the study of practices, technologies and iffrastructures through which different contemporary forms of subjectivity and objectuality are articulated. His recent work URIEL FOGUE

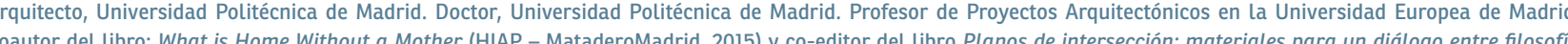

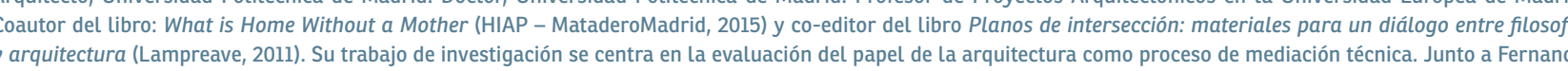

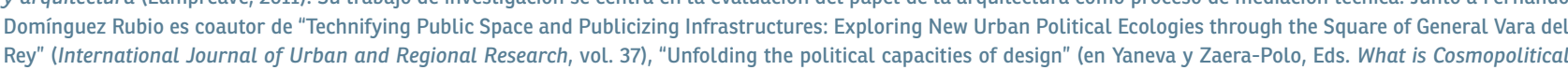

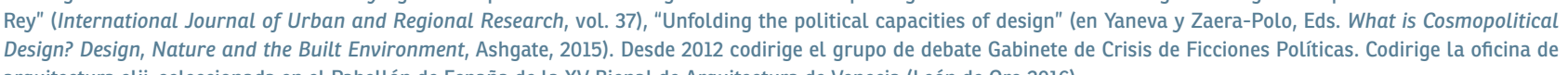

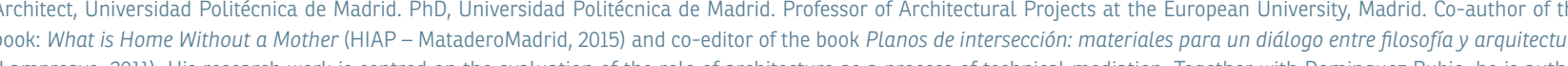

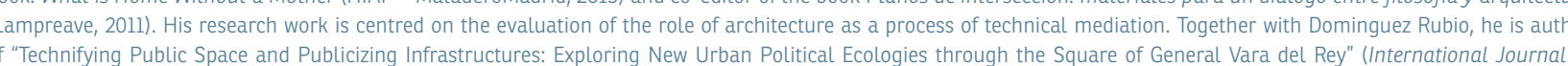

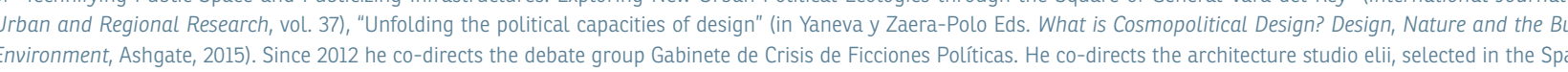

